\title{
MARKET COMPETITION FOR HIGH-DENSITY RESIDENTIAL LAND
}

\author{
Matthew L. CYPHER ${ }^{1}$ and Darren K. HAYUNGA ${ }^{2} \square$ \\ ${ }^{1}$ Invesco Real Estate, Three Galleria Tower, Suite 500, 13155 Noel Road, Dallas, Texas 75240, \\ USA \\ E-mail: matthew.cypher@invesco.com; Tel.: (972) 715-5843 \\ 2 Department of Finance and Real Estate, University of Texas at Arlington, Box 19449, Arling- \\ ton, TX 76019, USA \\ E-mail: hayunga@uta.edu; Tel.: (817)272-0518
}

Received 8 July 2009; accepted 24 November 2009

\begin{abstract}
We investigate the potential competition between multifamily and condominium developers for raw land throughout the U.S. When considering the entire sample period, we find evidence that condominium developers paid, on average, more for land than their multifamily counterparts. Alternatively, when we separate the sample into low versus high-growth locations and two time subperiods, we observe that the premium is not entirely consistent. The average premiums appear to be largely a result of the high-growth locations from 2004 to mid-2008. Indeed, the results demonstrate that condominium developers paid over 60 percent more for land in high-growth states during the later subperiod. This extraordinary premium calls into question the price formation process in these locations.
\end{abstract}

KEYWORDS: High-density residential land; Condominium development; Apartment development; Construction market; Undeveloped land

\section{INTRODUCTION}

We examine a potential relationship between the multifamily space market and the condominium asset market. Generally, the space and asset markets are considered separate with demand and supply equilibriums unique to each marketplace. In the space market, demand consists of renters willing to pay to use space for consumption or production purposes while supply consists of property owners willing to rent such space to users. In contrast, the asset market is made up of buyers and sellers concerned with the amount and timing of cash flows. Agents in the asset market determine market prices using the three main factors of opportunity cost of capital, growth expectations, and risk.

Based upon the difference in these two markets, a conclusion could be reached that condominium developers in the asset market and multifamily developers in the space market are two different types of agents. Condominium developers focus on the eventual price per square foot they can command upon sale of the development project while apartment developers focus on rents and occupancy rates. Hence, even though both developers produce high-density residential buildings, the separation of their respective markets implies they function in divergent arenas. 
But the fact that both condominium and apartment developers use land eventually zoned for high-density residential use as the foundation for their respective projects makes us question whether they are indeed two different types of agents. Indeed, while the land is one input of products destined for use and sale in divergent markets, we expect that the renter in a multifamily complex will desire many of the same neighborhood characteristics as a condominium owner e.g., close to shopping, transportation, and entertainment. Accordingly, these two agents should compete in the development portion of the real estate system given the substitutability of raw land for either use. And given the generally fixed and limited supply of land in most metropolitan areas in the short term, we should expect price formation and property valuation based upon both parties' demand for the same property.

The contrary nature of these two thoughts suggests a quantitative study examining whether there exists any consistent interaction between multifamily and condominium developers for the purchase of land. We can envision the full spectrum of possibilities. When the rental market is strong, multifamily developers may be able to outbid condominium builders. Of course, the reciprocal is also true when condominium sale prices are better. In contrast to these two boundaries is the potential for no systematic relation as both agents are able to compete and build projects in the same localized area.

When we formalize the research question of whether a systematic price relationship exists for high-density residential land, we initially find that condominium developers pay a premium. However, when we divide the sample based upon states that experience a lower versus higher appreciation in prices, we observe an inconsistent premium. In states with below-average growth from 1999 to 2003, we find condominium developers paid nearly 9 percent more than their multifamily counterparts.
While the results demonstrate a premium of similar magnitude in the above-average growth markets during the same time period (19992003) and the below-average growth markets from 2004 to mid-2008, the coefficient is statistically insignificant.

In contrast to the marginal premium in the previous three subsamples, the results demonstrate that condominium developers paid over 60 percent more for land than multifamily developers from 2004 to mid-2008 in the aboveaverage growth markets. As we have come to know, 2004-2006 was an exuberant period in real estate, potentially to the point of irrational valuation in certain markets. Thus, the results suggest that the ability to sell condominiums during this period eclipsed the rental market such that condominium developers possibly paid speculative prices for the property. Of course, the excessive premium paid by condominium developers calls into question the price formation process in above-average growth markets and the validity of these transactions as sales comparables.

In summary, the lack of a consistent price premium implies the ability of both types of developers to be competitive within a localized market. This fact is entirely consistent with observed market behavior. We describe the empirical evidence supporting this summation as well as provide additional information about the two different development markets in the remainder of the paper.

\section{RECENT MARKET CONDITIONS}

We examine the sample period from 1999 to mid-2008, which clearly corresponds to a bull market in the real estate industry. After the burst of the Internet bubble in 2000, investors began to look more seriously at real estate as an alternative investment to stocks and bonds. This interest came on the heels of falling real estate prices during the 1990s due to decreases in occupancy rates and rents. As capital poured 
into real estate after 2000, prices began to rebound. The price increases were pronounced in residential real estate and throughout the developed world save Japan and Germany. Based upon the S\&P/Case-Shiller U.S. index, residential property appreciated 109 percent from 1999 to the peak in 2006-an average rate over 10 percent per year.

As residential values appreciated, homeowners found an extra asset on their personal balance sheet in the form of home equity. Paired with low interest rates brought on by the Internet bust, many owners realized the equity through sale or borrowed against it by refinancing their homes. Subsequently, these owners used some of the acquired funds to stimulate their general consumption and the overall economy. In a similar manner, condominium owners participated in the boom of the broader residential housing market. As example, the average New York City condominium appreciated over 17 percent per annum from 1999 to the peak at the end of 2005 based upon the S\&P/Case-Shiller condominium index. Hence, in the context of this paper, condominium owners realized an increase in wealth based upon their equity position as compared to apartment renters. Presumably, the increase in condominium prices in the asset market promoted additional condominium development and a propensity for condominium developers to bid up the land price.

We see a similar reaction in a condominium-conversion study by Benjamin et al. (2008). They find that Miami-Fort Lauderdale condominium converters paid a premium for apartment complexes during the growth period from 2004-2006. They attribute the premium to condominium converters updating the property's occupant mix or letter grade-something not afforded to renters. In the context of our analysis, we question whether there is a similar price formation in U.S. land based upon asset versus space markets.

\section{RELEVANT THEORY AND LITERATURE}

As best as we can determine, this paper is the first to consider the valuation of land used in the development of high-density residential property. Alternatively, the context of our empirical study fits within the well known Real Estate System. Figure 1 presents a visual overview of the system as shown in Geltner and Miller (2001).

Figure 1 shows the three main elements of the System-the space market, the asset market, and the development industry. Within the space market, the current stock of physical space interacts with tenants' requirements, which determines rents and occupancy. The output of the space market is cash flow, which is one component of a specific property's value. The other factor that assists in determining a property's market value is the market required capitalization rate, which itself is a function of investors buying and selling. Of course, the space and asset markets are affected by overall economic conditions, which, along with the capital markets, lead to forecasts of future supply and demand.

The other element where future forecasts are a crucial input is the development industry-the focus of our study. From the asset market and the associated property market values, developers consider the profitability of new supply. As Geltner and Miller (2001) point out, a key component of the development process is the opportunity value of the land. This opportunity value is determined in the asset market since land is an investable asset.

The interaction of the three primary elements of the real estate system can be represented graphically in a general equilibrium framework. The models of Fisher (1992) and DiPasquale and Wheaton (1992) allow for longrun comparative static analysis of the relationship between the real estate space and asset markets. Geltner and Mei (1995) formally specify the Fisher (1992) and DiPasquale and 


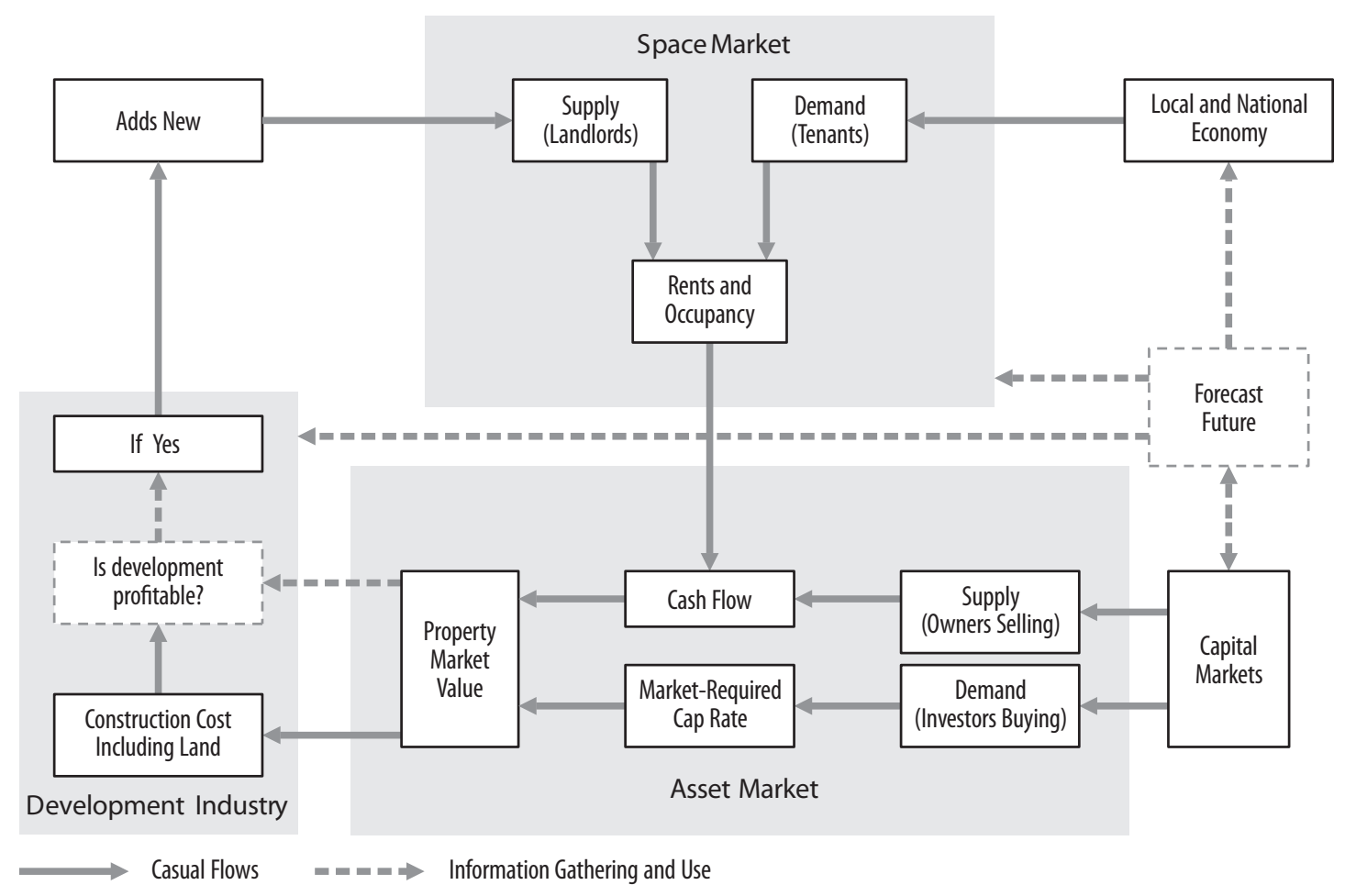

Figure 1. The real estate system.

Wheaton (1992) models using the asset return identity $r_{t+1} \approx \log \left(P_{t+1}+D_{t+1} / P_{t}\right)$, and obtain a first-order Taylor expansion of

$$
\begin{aligned}
& r_{t+1} \approx \alpha+\rho \log P_{t+1}+ \\
& (1-\rho) \log D_{t+1}-\log P_{t}
\end{aligned}
$$

where the parameter $\rho$ is the average asset price scaled by the sum of the asset price and cash flow, and the constant $\alpha$ is a nonlinear function of $\rho$. Following Geltner and Mei (1995) as well as Eppli et al. (1998), Equation (1) can be rewritten as an expectational difference equation and, by not allowing for explosive rational asset prices, can be solved forward as

$$
\begin{aligned}
& \log P_{t}=\frac{\alpha}{1-\rho}+(1-\rho) \sum_{j=0}^{\infty} \rho^{i} \mathrm{E}_{t}\left(\log D_{t+1+j}\right)- \\
& \sum_{j=0}^{\infty} \rho^{j} \mathrm{E}_{t}\left(r_{t+1+j}\right) .
\end{aligned}
$$

Equation (2) shows that the observed asset price is equal to the expected discounted value of all future cash flow $\left(D_{t+1+j}\right)$ less future returns $\left(r_{t+1+j}\right)$. These factors provide linkage as the cash flows account for expectations in the space market and the returns reflect expectations in the capital markets; both of which impact the value of the property in our study.

While not as formal as Geltner and Mei (1995) and Eppli et al. (1998), we can summarize well the main research hypothesis of this paper using DiPasquale and Wheaton (1992) model, which we reproduce in Figure 2. The dotted rectangle-the vertical and horizontal sides of which connect between tangent points in each quadrant-represents long-run equilibrium. The point where the sides of the rectangle cross the axes note the equilibrium 


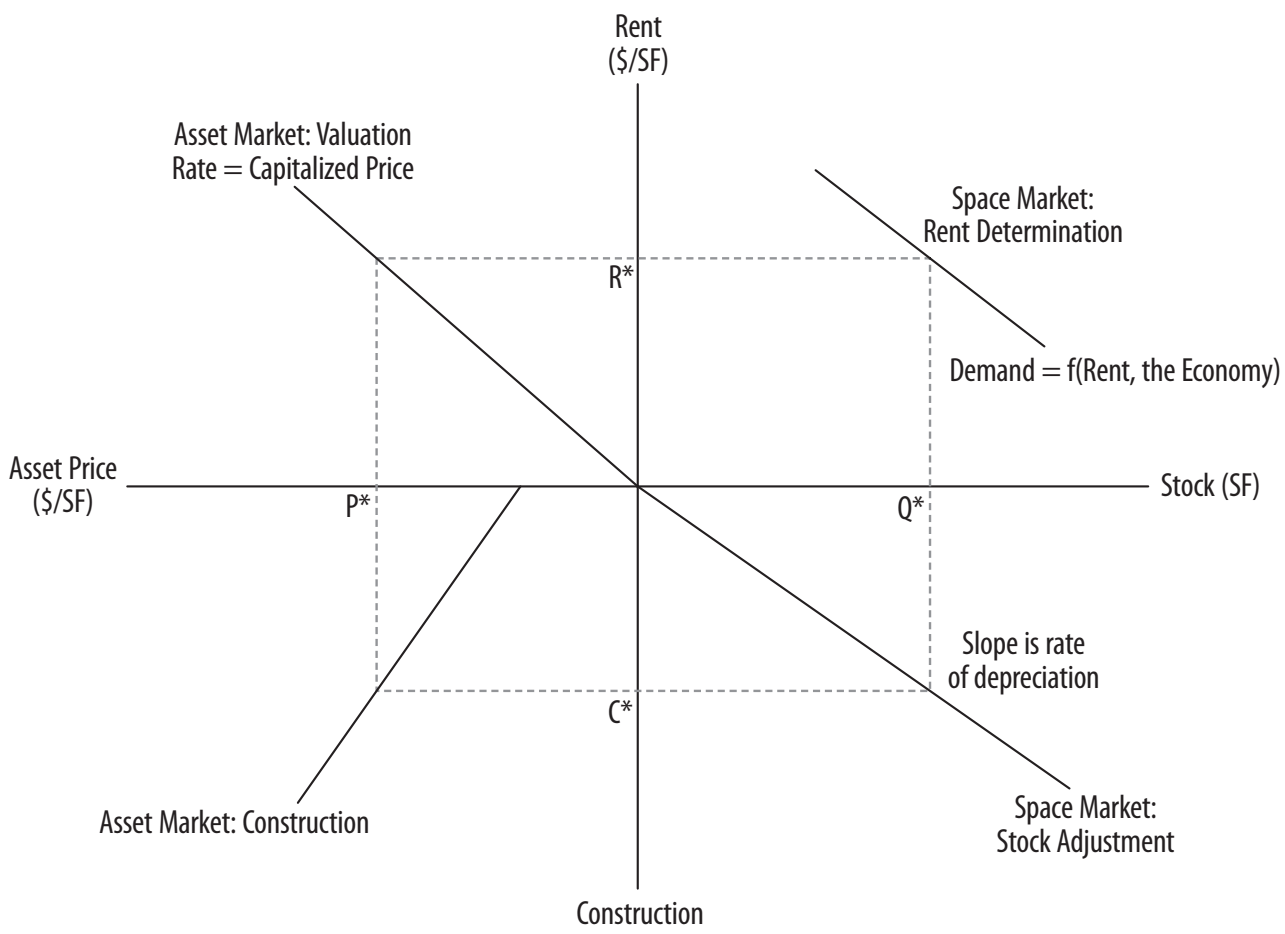

(SF)

Figure 2. The Four-quadrant model of DiPasquale and Wheaton (1992).

stock of built space, rent, asset prices, and the rate of new construction $\left(\mathrm{Q}^{*}, \mathrm{R}^{*}, \mathrm{P}^{*}\right.$, and $\mathrm{C}^{*}$ respectively).

To decompose the model, we begin in the southeast quadrant, which represents the classical stock and flow nature of the real estate system. That is, the slope of the line in the southeast quadrant is the relationship between the stock of real estate and the flow of construction required to retain such a stock in the steady state. This is the level of construction required to cover depreciation, abandonment, and demolition.

Drawing a vertical line through the current supply of real estate stock $\left(Q^{*}\right)$ into the northeast quadrant, we find the determination of equilibrium rent. The price per square feet is that point $\left(R^{*}\right)$ where the vertical line through $\mathrm{Q}^{*}$ intersects the demand function in the northeast quadrant. The slope of the demand being a function of rent and exogenous economic conditions.

Given $R^{*}$, the northwest quadrant is the wellknown present value relationship. The asset market valuation process relates equilibrium property pries $\left(\mathrm{P}^{*}\right)$ to equilibrium rents $\left(\mathrm{R}^{*}\right)$ with the resulting slope of the line from the origin being the familiar cap rate. The steeper this line, the higher the cap rate.

Lastly, drawing a vertical line down from the cap rate determined by equilibrium rent and price, we arrive in the southwest quadrant and the market for new construction. This quadrant presents the operation of the development industry-the focus of this study. The southwest quadrant simply presents the supply curve for real estate construction. 
While demand is in terms of flow (i.e. price is measured by rents), developers will decide how much new real estate to supply depending on the asset valuation. Thus, the relevant price in the southwest quadrant is the asset price. That is not to say that income-producing property such as a multifamily development does not value interim rents. Instead, these rents are capitalized into asset value; equilibrium asset prices being the ultimate determinant of new construction-whether multifamily or condominiums development.

Additionally, the construction line depicts the positive relation between asset prices and new development. For example, higher property prices will allow for previously unjustifiable construction to begin. The construction line intersects the price axis at a positive amount instead of at the origin because construction will halt if prices fall below a certain threshold. Given the value of assets from the northwest quadrant, a vertical line from construction cost curve and then over to the vertical axis determines the level of new construction $\left(\mathrm{C}^{*}\right)$ where construction costs equal asset prices. The horizontal line through $\mathrm{C}^{*}$ thus completes the four-quadrant diagram with the level of construction linking with the equilibrium stock of built space where they intersect in the space market.

In summary, both the Real Estate System and the DiPasquale and Wheaton (1992) model show the potential competition between multifamily and condominium developers. In both models, developers will bid for land based upon the property market value in the asset market. Consequently, our first investigation is to determine whether one property type systematically realizes higher returns over the other such that the developer of that property type could consistently outbid the competitor. Using data from Moodys/Real and the National Association

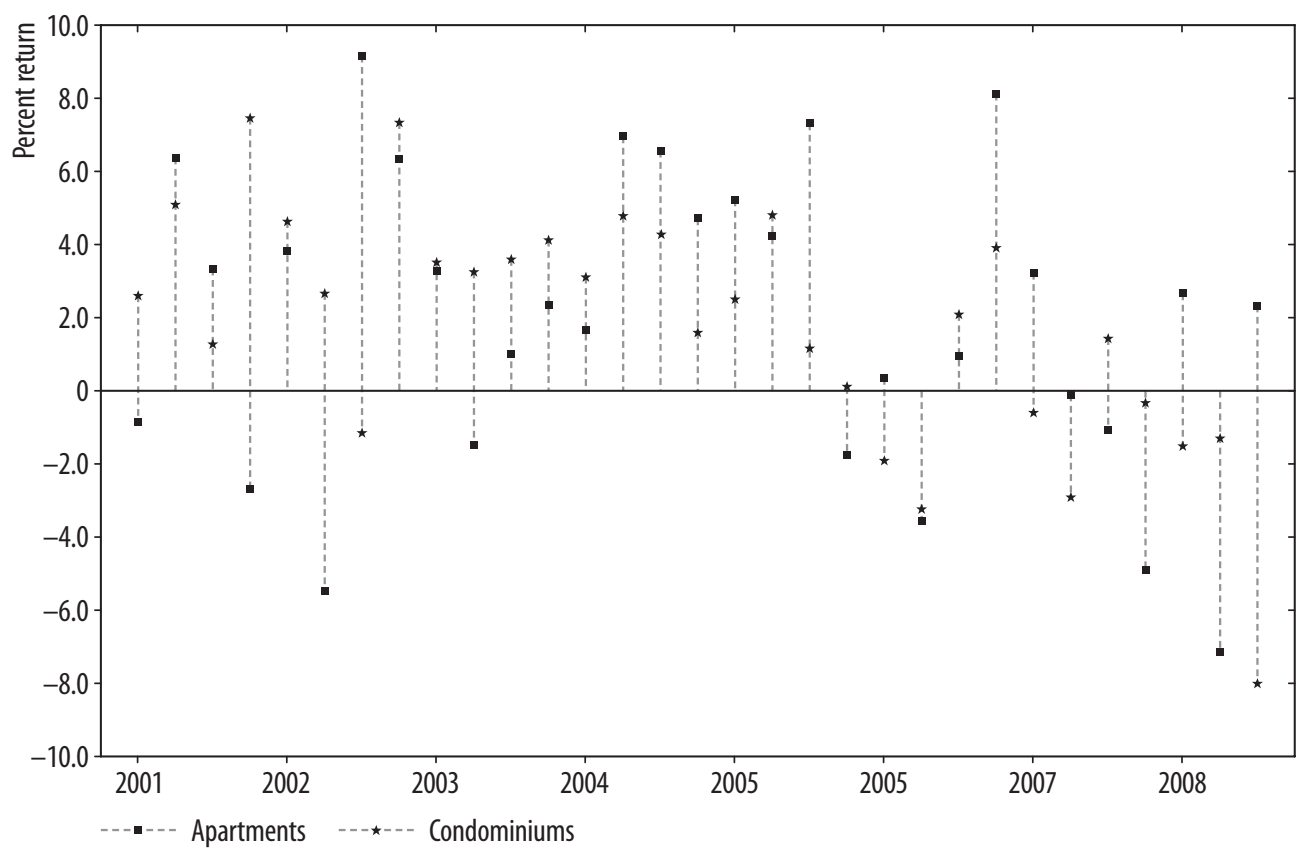

Figure 3. National quarter returns for apartment and condominium complexes. Apartment data from Moodys/Real Commercial Property Index. Condominium data from the National Association of Realtors. 
of Realtors, Figure 3 shows that systematically higher returns did not accrue to one property type over the other from 2001 to 2008. In fact, the split of higher returns is almost even-out of the 31 quarterly observations in Figure 3, apartment returns were higher in 17 instances while condominiums realized higher returns in 14 quarters.

\section{RESEARCH DESIGN}

Since the national returns of one property type are not consistently higher than the other, we next examine specific land transactions designated for condominium or multifamily development. We obtain all U.S. transactions in the CoStar database from 1990 to August, 2008. We remove the observations prior to 1999 since there are only 22 for the 8-year period. Additionally, we remove 64 records for a lack of data required in subsequent empirical models. The final dataset consists of 5,623 observations.

Upon finalizing the sample, we again investigate an initial systematic relationship; this time in the property-specific transaction prices. We compute the mean and median prices for each year to examine if one property type consistently realizes smaller prices since lower land costs will assist a developer with the overall property return. Figure 4 displays the results. It is not entirely clear from Figure 4 that there exists a consistent relation between these summary prices. Both the mean and median prices are higher for land designated for multifamily development from 1999 to 2001. Conversely, land designated for condominiums garnered higher mean and median transaction prices during 2002-2005. Beginning in 2006, condominium median prices are lower but the

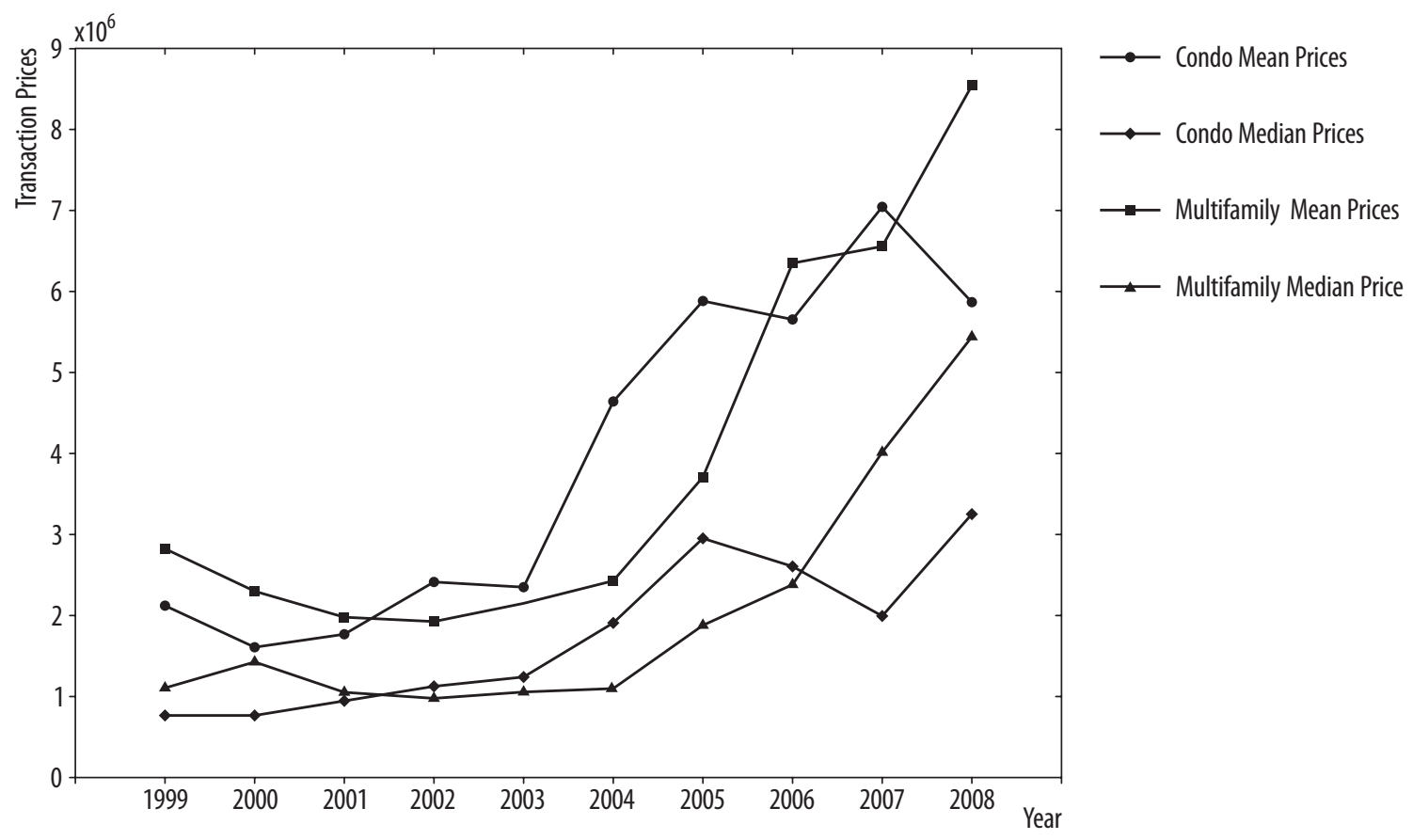

Figure 4. Mean and median transaction prices for land designated for either condominium or multifamily development. 
mean prices are mixed relative to multifamily mean values. Since neither the national returns nor the specific transaction prices yield a systematic relation between the property types, we proceed with empirically modeling the price of each transaction. We model six main determinants of price. Table 1 details summary statistics sorted by the eventual development type.

Table 1. This table presents descriptive statistics for U.S. land designated for either condominium or multifamily developments

\begin{tabular}{|c|c|c|c|c|c|}
\hline & Mean & Median & Std. Dev. & Minimum & Maximum \\
\hline \multicolumn{6}{|c|}{ Condominium developments $(\mathrm{N}=2,571)$} \\
\hline Price & $\$ 3,645,929$ & $\$ 1,435,000$ & $\$ 8,431,366$ & $\$ 30,000$ & $\$ 185,000,000$ \\
\hline SQFT & 208,248 & 45,624 & 512,997 & 344 & $9,401,119$ \\
\hline Income & $\$ 52,387$ & $\$ 50,846$ & $\$ 8,451$ & $\$ 35,952$ & $\$ 83,646$ \\
\hline Res Demand & 57,593 & 26,349 & 14,295 & 676 & 68,918 \\
\hline OutState & 0.08 & 0.00 & 0.26 & 0.00 & 1.00 \\
\hline CBD & 6.52 & 4.95 & 4.86 & 0.09 & 19.95 \\
\hline Yr1999 & 0.03 & 0.00 & 0.17 & 0.00 & 1.00 \\
\hline Yr2000 & 0.14 & 0.00 & 0.34 & 0.00 & 1.00 \\
\hline Yr2001 & 0.11 & 0.00 & 0.32 & 0.00 & 1.00 \\
\hline Yr2002 & 0.12 & 0.00 & 0.33 & 0.00 & 1.00 \\
\hline Yr2003 & 0.13 & 0.00 & 0.34 & 0.00 & 1.00 \\
\hline Yr2004 & 0.17 & 0.00 & 0.37 & 0.00 & 1.00 \\
\hline Yr2005 & 0.17 & 0.00 & 0.37 & 0.00 & 1.00 \\
\hline Yr2006 & 0.08 & 0.00 & 0.29 & 0.00 & 1.00 \\
\hline Yr2007 & 0.04 & 0.00 & 0.21 & 0.00 & 1.00 \\
\hline Yr2008 & 0.01 & 0.00 & 0.08 & 0.00 & 1.00 \\
\hline \multicolumn{6}{|c|}{ Multifamily developments $(\mathrm{N}=3,052)$} \\
\hline Price & $\$ 2,964,719$ & $\$ 1,349,500$ & $\$ 5,967,609$ & $\$ 36,500$ & $\$ 136,500,000$ \\
\hline SQFT & 402,891 & 95,091 & $1,295,815$ & 609 & $40,553,488$ \\
\hline Income & $\$ 52,799$ & $\$ 52,719$ & $\$ 7,714$ & $\$ 36,212$ & $\$ 84,729$ \\
\hline Res Demand & 29,956 & 29,324 & 15,033 & 594 & 73,335 \\
\hline OutState & 0.15 & 0.00 & 0.36 & 0.00 & 1.00 \\
\hline CBD & 6.52 & 5.43 & 4.56 & 0.03 & 19.98 \\
\hline Yr1999 & 0.04 & 0.00 & 0.20 & 0.00 & 1.00 \\
\hline Yr2000 & 0.14 & 0.00 & 0.34 & 0.00 & 1.00 \\
\hline Yr2001 & 0.15 & 0.00 & 0.35 & 0.00 & 1.00 \\
\hline Yr2002 & 0.14 & 0.00 & 0.35 & 0.00 & 1.00 \\
\hline Yr2003 & 0.15 & 0.00 & 0.35 & 0.00 & 1.00 \\
\hline Yr2004 & 0.14 & 0.00 & 0.35 & 0.00 & 1.00 \\
\hline Yr2005 & 0.11 & 0.00 & 0.32 & 0.00 & 1.00 \\
\hline Yr2006 & 0.06 & 0.00 & 0.24 & 0.00 & 1.00 \\
\hline Yr2007 & 0.05 & 0.00 & 0.22 & 0.00 & 1.00 \\
\hline Yr2008 & 0.02 & 0.00 & 0.14 & 0.00 & 1.00 \\
\hline
\end{tabular}


The first rows in the panels of Table 1 show that the overall mean and median prices paid by condominium developers are greater than multifamily developers. We confirm that this is not a function of extreme outliers. When we remove the two highest price observations from the condominium panel-which leaves a maximum value lower than the maximum in the multifamily subset-the condominium mean and median prices $(\$ 3,515,525$ and $\$ 1,435,000$, respectively) are still greater than the multifamily prices.

Alternatively, land designated for multifamily development exhibits a larger footprint than condominium-designated properties. The square feet size of condominium land is 208,248 . The size of multifamily-designated land is almost twice the area at 402,891 square feet (the median size of multifamily-designated is greater than 200 percent). There are five observations in the multifamily subset that are greater than the largest condominium parcel. When we exclude these potential outliers we observe similar maximum values across both datasets. However, we still find that the multifamily mean size is 361,278 while the median is 94,089 ; amounts greater than the condominium-designated subset.

While the summary statistics suggest that the average price paid by condominium developers for residential property is greater than multifamily developers-especially in light of the notable difference in footprint-there are clearly other determinants of land transaction prices. We include these explanatory variables in the following model.

$$
\begin{aligned}
& \operatorname{Ln}(\text { Price })=\beta_{0}+\delta \cdot \text { DevType }+\beta_{1} . \\
& \text { SqFt }+\beta_{2} \cdot \mathrm{SqFt}^{2}+\beta_{3} \cdot \text { Income }+ \\
& \beta_{4} \cdot \operatorname{ResDemand}+\beta_{5} \cdot \text { OutState }+ \\
& \beta_{6} \cdot \mathrm{CBD}+\beta_{7} \cdot \Delta \text { Employment }+ \\
& \beta_{8} \cdot \text { Latitude }+\beta_{9} \cdot \text { Latitude }^{2}+\beta_{10} . \\
& \text { Longitude }+\beta_{11} \cdot \text { Longitude }^{2}+ \\
& \sum_{\mathrm{t}=1999}^{2008} \alpha_{\mathrm{t}} \cdot \mathrm{Yr}_{\mathrm{t}}+\varepsilon_{\mathrm{i}}
\end{aligned}
$$

The main variable of interest is Dev Type and the associated coefficient $\delta$. Dev Type is a dichotomous variable coded as 1 for land designated for condominium development or 0 for multifamily-designated land. Any significant value for $\delta$ demonstrates one type of development designation has an effect on transaction prices-the null hypothesis being $\delta=0$.

A challenge in modeling land prices is that there are not many individual-properties characteristics to control for. Clearly, the size of the property can be a determinant, thus we include square feet $(\mathrm{SqFt})$ and square feet squared $\left(\mathrm{SqFt}^{2}\right)$ as price should increase as the property size increases but at a decreasing rate.

Beyond individual characteristics we look to determinants within the metropolitan area. We control for the income of a metropolitan area as a demand-side driver of the market. We also proxy for residential housing (Res Demand), which is the total apartments units permitted in a given metropolitan area. Of course, the change in population will also influence the demand for residential housing. As Miles et al. (2007, p. 20) note, real estate development is a function of not just an increase in population but an increase in population with purchasing power. We find changes in population and employment are correlated at greater than 0.98 , therefore, we include the change in employment in the model. ${ }^{1}$

Ostensibly, the key component to any specific parcel of land is its location. Since there are not distinguishing features such as building size and construction material for property, a developer will probably determine a bid price largely on the location of the parcel to other amenities. Due to its importance, we control for location two ways. First, in keeping with the classic bid-rent curve, we geocode the property location and compare it to the central business

\footnotetext{
${ }^{1}$ We capture employment and population levels using year dummies.
} 
district. The variable, CBD, is the number of miles of separation distance between the subject property and the central business district. The second method to capture specific location is to use the actual Cartesian $\{\mathrm{x}, \mathrm{y}\}$ coordinates. A study by Fik et al. (2003) demonstrates that the absolute location of a parcel has a unique location-value signature that can be captured through the Cartesian coordinates. This method is potentially better than distant gradients or numerous dummy variables given the indeterminable number of externalities that affect a property's value. The variables, Latitude and Longitude, are the Cartesian coordinates. Consistent with Fik et al. (2003), we also use Latitude $^{2}$ and Longitude ${ }^{2}$-squared values of the base latitude and longitude.

The last control variables are OutState and dichotomous variables for each year in the sample period. ${ }^{2}$ Lambson et al. (2004) find that out-of-state buyers pay a premium for commercial real estate, hence, we include a dummy variable to capture this effect.

\section{EMPIRICAL RESULTS}

We begin the empirical analysis by applying the model to the full sample of land transactions. Column 1 in Table 2 details the results. The coefficient on the main variable of interest, Dev Type, is 0.22 and statistically significant. Using Kennedy (1981) for correct interpretation of a dummy variable in semilog equations, the coefficient value equates to a premium of $\$ 759,338$ paid by condominium developers, on average-the mean price for all land in the sample being almost $\$ 3.3$ million.

\footnotetext{
${ }^{2}$ We also investigate the T-bill rate as a proxy for cost of capital. This proxy is highly correlated with the year variables and causes multicollinearity in the model. We use the dichotomous year variables in lieu of the proxy for the cost of capital since the dummies for each sample year allows us more flexibility i.e., some other market characteristic or shock may affect prices in any one year that may not be observed in the specific T-bill rate.
}

Table 2. The table reports coefficients and heteroscedasity-consistent t-statistics (in parentheses) of models used to explain the natural logarithm of transaction price for a sample of U.S. land designated for either condominium or multifamily development

\begin{tabular}{|c|c|c|c|}
\hline & $\begin{array}{l}\text { Full Sample } \\
(\mathrm{N}=5,623)\end{array}$ & $\begin{array}{l}1999-2003 \\
(\mathrm{~N}=3,254)\end{array}$ & $\begin{array}{l}2004-2008 \\
(\mathrm{~N}=2,369)\end{array}$ \\
\hline Dev Type & $\begin{array}{l}0.22 \\
(7.71)^{* * * *}\end{array}$ & $\begin{array}{l}0.13 \\
(3.34)^{* * *}\end{array}$ & $\begin{array}{l}0.36 \\
(5.81)^{* * *}\end{array}$ \\
\hline SQFT & 4.81 & 5.97 & 4.11 \\
\hline$\left(* 10^{-7}\right)$ & $(7.19)^{* * *}$ & $(5.35)^{* * *}$ & $(0.76)$ \\
\hline $\mathrm{SQFT}^{2}$ & -1.24 & -1.87 & -0.09 \\
\hline$\left(* 10^{-4}\right)$ & $(-2.56)^{* *}$ & $(-1.73)^{*}$ & $(-0.09)$ \\
\hline Income & 0.25 & 0.24 & 0.24 \\
\hline$\left(* 10^{-4}\right)$ & $(9.70)^{* * *}$ & $(6.81)^{* * *}$ & $(6.05)^{* * *}$ \\
\hline Res Demand & 0.08 & 0.05 & 0.12 \\
\hline$\left(* 10^{-4}\right)$ & $(8.36)^{* * *}$ & $(3.88)^{* * *}$ & $(7.20)^{* * *}$ \\
\hline \multirow[t]{2}{*}{ OutState } & 0.51 & 0.43 & 0.56 \\
\hline & $(10.69)^{* * *}$ & $(7.42)^{* * *}$ & $(7.02)^{* * *}$ \\
\hline \multirow[t]{2}{*}{$\mathrm{CBD}$} & -0.02 & -0.02 & -0.01 \\
\hline & $(-5.79)^{* * *}$ & $(-6.02)^{* * *}$ & $(-1.02)$ \\
\hline \multirow[t]{2}{*}{$\Delta$ Employment } & -0.04 & -0.05 & -0.02 \\
\hline & $(-2.07)^{* *}$ & $(-1.93)^{*}$ & $(-0.24)$ \\
\hline \multirow[t]{2}{*}{ Latitude } & -0.19 & -0.20 & -0.16 \\
\hline & $(-6.51)^{* * *}$ & $(-5.32)^{* * *}$ & $(-3.15)^{* * *}$ \\
\hline \multirow[t]{2}{*}{ Latitude $^{2}$} & 0.00 & 0.00 & 0.00 \\
\hline & $(5.11)^{* * *}$ & $(4.23)^{* * *}$ & $(2.48)^{* *}$ \\
\hline \multirow[t]{2}{*}{ Longitude } & 0.10 & 0.08 & 0.12 \\
\hline & $(5.95)^{* * *}$ & $(3.63)^{* * *}$ & $(3.47)^{* * *}$ \\
\hline \multirow[t]{2}{*}{ Longitude $^{2}$} & 0.00 & 0.00 & 0.00 \\
\hline & $(6.27)^{* * *}$ & $(3.78)^{* * * *}$ & $(3.68)^{* * *}$ \\
\hline \multirow[t]{2}{*}{ Yr2000 } & -0.01 & -0.05 & \\
\hline & $(-0.16)$ & $(-0.44)$ & \\
\hline \multirow[t]{2}{*}{ Yr2001 } & -0.13 & -0.26 & \\
\hline & $(-1.50)$ & $(-2.00)^{* *}$ & \\
\hline \multirow[t]{2}{*}{ Yr2002 } & -0.07 & -0.30 & \\
\hline & $(-0.81)$ & $(-1.56)$ & \\
\hline \multirow[t]{2}{*}{ Yr2003 } & 0.04 & -0.27 & \\
\hline & $(0.50)$ & $(-1.05)$ & \\
\hline Yr2004 & 0.28 & & \\
\hline
\end{tabular}

$(3.53)^{* * *}$ 


\begin{tabular}{llll}
\hline & $\begin{array}{l}\text { Full Sample } \\
(\mathrm{N}=5,623)\end{array}$ & $\begin{array}{l}1999-2003 \\
(\mathrm{~N}=3,254)\end{array}$ & $\begin{array}{l}2004-2008 \\
(\mathrm{~N}=2,369)\end{array}$ \\
\hline Yr2005 & 0.57 & & \\
& $(6.86)^{* * *}$ & -0.09 \\
Yr2006 & 0.61 & $(-0.83)$ \\
& $(6.47)^{* * *}$ & & -0.36 \\
Yr2007 & 0.65 & & $(-2.01)^{* *}$ \\
& $(6.10)^{* * *}$ & & -0.66 \\
Yr2008 & 1.12 & & $(-2.17)^{* *}$ \\
& $(7.79)^{* * *}$ & & -0.38 \\
Intercept & 21.08 & 17.16 & $(-0.89)$ \\
& $(25.16)^{* * *}$ & $(6.15)^{* * *}$ & $(1.18)$ \\
Adjusted $\mathrm{R}^{2}$ & 0.24 & 0.17 & 0.19 \\
\hline
\end{tabular}

Sample period is 1999 to mid-2008.

$* * *, * *$, and * denote statistical significance at the 10 , 5 , and 1 percent levels, respectively.

Many of the other covariates also explain national land transaction prices. As expected, values increase with the size of the parcel (SQFT) at a decreasing rate (SQFT2). There is also a positive relationship between land prices and greater metropolitan area income as well as the total apartments units permitted in a given metropolitan area. Another positive relation, which is rather substantial, is the premium paid by out-of-state buyers. The 0.51 parameter estimate implies a premium of $\$ 2,037,667$.

At the bottom of Column 1, the various year dummies exhibits a difference in price over the sample period. Using 1999 as the base, the results demonstrate that 2000-2003 prices are similar to 1999, however, 2003-2008 prices are statistically different. To examine the importance of this possible structural break in prices over time, we split the sample and report the results in Columns 2 and 3 of Table 2.

Splitting the sample into two time periods appears to further refine the results as the annual qualitative variables are not highly significant for either Column 2 or 3 . We observe that the Dev Type coefficient changes materially. The results for 1999-2003 in Column 2 demonstrate that the difference paid by condominium versus multifamily developers decreases relative to the full sample from 0.22 to 0.13 (\$371,000). Conversely, the Dev Type coefficient increases for 2004-2008 to 0.36. This equates to a substantial premium of $\$ 1,272,430$ paid by condominium developers.

The value of the Dev Type appears to be of such importance that it subsumes the explanatory value on SQFT and CBD. Further, whereas the t-statistic on the intercept in the full sample in Column 1 is over 25 standard errors from zero, the constant term in Column 3 is not significant. The final item we note-in addition to the fact that the latitude and longitude variables are significant across all models-is the difference in the premium paid by out-of-town buyers for the two time periods. From 19992003 , the premium of 0.43 equates to $\$ 1,613,623$ while the premium in the later period is 0.56 or $\$ 2,254,270-$ an increase of 40 percent.

\subsection{Geographic location}

We are generally not surprised that there exists a structural break creating two distinct time periods. Clearly, 2004-2007 was an exhilarating time in commercial real estate. Returns on the NCREIF national index are 7.28, 6.75, and 9.00 for 2001-2003 and 14.49, 20.06, 16.60 , and 15.85 percent from 2004 to 2007. But we question whether these differences in returns are a reflection of differing time periods or a function of exuberance in specific markets. For example, it has become common knowledge that certain markets in California, Arizona, Nevada, and Florida were quite "hot" during the later time period of our sample. We note that the 2004-2007 NCREIF returns for the West portion of the U.S. are 15.34, 21.04, 18.45 , and 18.29 percent versus $12.50,14.10$, 11.46 , and 13.52 percent for the South region, respectively.

To determine if geographic location has an effect on the value multifamily and condominium developers pay for land, we separate the 
sample into two subsamples using the standard deviation of transaction prices for each state. Scheinkman and Xiong (2003) show that an outcome of an asset bubble is an increase in price volatility. Hence, we split the sample into low standard deviation (low-growth) versus high standard deviation (high-growth) states and model transaction prices. Table 3 details the states and standard deviations. ${ }^{3}$

Table 3. The table reports the standard deviation of the natural logarithm of trans-action prices by state

\begin{tabular}{|c|c|c|c|}
\hline & State & $\begin{array}{l}\text { Number of } \\
\text { observations }\end{array}$ & $\begin{array}{l}\text { Standard } \\
\text { deviation }\end{array}$ \\
\hline \multirow{11}{*}{$\begin{array}{l}\text { Low } \\
\text { standard } \\
\text { deviation } \\
\text { of Log(Price) }\end{array}$} & $\mathrm{OH}$ & 160 & 0.80 \\
\hline & $\mathrm{NC}$ & 61 & 0.87 \\
\hline & MI & 157 & 0.88 \\
\hline & $\mathrm{CO}$ & 256 & 0.96 \\
\hline & MA & 244 & 0.97 \\
\hline & PA & 54 & 0.99 \\
\hline & $\mathrm{TX}$ & 218 & 1.00 \\
\hline & $\mathrm{AZ}$ & 290 & 1.01 \\
\hline & FL & 815 & 1.03 \\
\hline & WA & 304 & 1.04 \\
\hline & OR & 96 & 1.04 \\
\hline \multirow{9}{*}{$\begin{array}{l}\text { High } \\
\text { standard } \\
\text { deviation } \\
\text { of } \log (\text { Price) }\end{array}$} & NJ & 189 & 1.09 \\
\hline & $\mathrm{NV}$ & 145 & 1.10 \\
\hline & GA & 192 & 1.11 \\
\hline & $\mathrm{DC}$ & 92 & 1.13 \\
\hline & $\mathrm{MD}$ & 115 & 1.13 \\
\hline & $\mathrm{CA}$ & 915 & 1.15 \\
\hline & IL & 364 & 1.15 \\
\hline & VA & 130 & 1.17 \\
\hline & NY & 751 & 1.34 \\
\hline
\end{tabular}

Separating the sample by standard deviation yields the findings in Table 4 . The results for the low-growth subsample in Column 1 demonstrate a premium paid by condominium developers of 0.11 or $\$ 308,468$. Alternatively, condominium developers paid a premium of 0.32 or nearly $\$ 1,077,000$ for land in the

\footnotetext{
3 The CoStar database yields observations from 30 states, however, 6 states offer less than 5 observations each. We require at least 30 observations to be in the subsample.
}

states that experienced the greatest range in transaction prices. The net effect is that condominium developers paid more than three times the amount for land in high priced states over what condominium developers paid in states where the price did not increase as much. Additionally, the Dev Type seemingly subsumes the importance of lot size, residential demand, and the latitude and longitude variables. Of note, out-of-state buyers pay a higher premium in the high standard deviation states-0.47 $(\$ 1,815,292)$ versus $0.64(\$ 2,700,285)$.

Table 4. The table reports coefficients and heteroscedasity-consistent $t$-statistics (in parentheses) of subsamples split by the standard deviation of the natural logarithm of transaction prices (the dependent variable)

\begin{tabular}{|c|c|c|}
\hline & $\begin{array}{l}\text { Low St.Dev. } \\
1999-2008 \\
(\mathrm{~N}=2,730)\end{array}$ & $\begin{array}{l}\text { High St.Dev. } \\
1999-2008 \\
(\mathrm{~N}=2,893)\end{array}$ \\
\hline Dev Type & $\begin{array}{l}0.11 \\
(2.91)^{* * * *}\end{array}$ & $\begin{array}{l}0.32 \\
(4.88)^{* * *}\end{array}$ \\
\hline $\begin{array}{l}\mathrm{SQFT} \\
\left({ }^{*} 10^{-7}\right)\end{array}$ & $\begin{array}{l}4.45 \\
(6.48)^{* * *}\end{array}$ & $\begin{array}{l}8.19 \\
(1.07)\end{array}$ \\
\hline $\begin{array}{l}\mathrm{SQFT}^{2} \\
\left({ }^{*} 10^{-14}\right)\end{array}$ & $\begin{array}{l}-0.11 \\
(-2.58)^{* * *}\end{array}$ & $\begin{array}{l}-3.85 \\
(-0.22)\end{array}$ \\
\hline $\begin{array}{l}\text { Income } \\
\left({ }^{*} 10^{-4}\right)\end{array}$ & $\begin{array}{l}0.31 \\
(7.27)^{* * *}\end{array}$ & $\begin{array}{l}0.22 \\
(5.94)^{* * *}\end{array}$ \\
\hline $\begin{array}{l}\text { Res Demand } \\
\left({ }^{*} 10^{-6}\right)\end{array}$ & $\begin{array}{l}8.46 \\
(4.74)^{* * *}\end{array}$ & $\begin{array}{l}3.43 \\
(1.42)\end{array}$ \\
\hline OutState & $\begin{array}{l}0.47 \\
(8.66)^{* * *}\end{array}$ & $\begin{array}{l}0.64 \\
(7.17)^{* * *}\end{array}$ \\
\hline $\mathrm{CBD}$ & $\begin{array}{l}-0.01 \\
(-2.88)^{* * *}\end{array}$ & $\begin{array}{l}-0.03 \\
(-3.60)^{* * *}\end{array}$ \\
\hline$\Delta$ Employment & $\begin{array}{l}-0.02 \\
(-0.79)\end{array}$ & $\begin{array}{l}-0.07 \\
(-2.12)^{* *}\end{array}$ \\
\hline Latitude & $\begin{array}{l}-0.32 \\
(-7.57)^{* * *}\end{array}$ & $\begin{array}{l}-1.18 \\
(-1.66)^{*}\end{array}$ \\
\hline Latitude $^{2}$ & $\begin{array}{l}0.00 \\
(6.46)^{* * *}\end{array}$ & $\begin{array}{l}0.02 \\
(1.61)\end{array}$ \\
\hline Longitude & $\begin{array}{l}0.06 \\
(2.76)^{* * *}\end{array}$ & $\begin{array}{l}0.09 \\
(1.19)\end{array}$ \\
\hline Longitude $^{2}$ & $\begin{array}{l}0.00 \\
(2.83)^{* * * *}\end{array}$ & $\begin{array}{l}0.00 \\
(1.25) \\
\text { (Continued) }\end{array}$ \\
\hline
\end{tabular}




\begin{tabular}{|c|c|c|}
\hline & $\begin{array}{l}\text { Low St.Dev. } \\
1999-2008 \\
(\mathrm{~N}=2,730)\end{array}$ & $\begin{array}{l}\text { High St.Dev. } \\
1999-2008 \\
(\mathrm{~N}=2,893)\end{array}$ \\
\hline \multicolumn{3}{|l|}{ (Continued) } \\
\hline \multirow[t]{2}{*}{ Yr2000 } & 0.07 & -0.09 \\
\hline & $(0.72)$ & $(-0.58)$ \\
\hline \multirow[t]{2}{*}{ Yr2001 } & 0.06 & -0.33 \\
\hline & $(0.64)$ & $(-2.09)^{* *}$ \\
\hline \multirow[t]{2}{*}{ Yr2002 } & 0.07 & -0.20 \\
\hline & $(0.73)$ & $(-1.26)$ \\
\hline \multirow[t]{2}{*}{ Yr2003 } & 0.22 & -0.11 \\
\hline & $(2.52)^{* *}$ & $(-0.66)$ \\
\hline \multirow[t]{2}{*}{ Yr2004 } & 0.35 & 0.23 \\
\hline & $(3.94)^{* * *}$ & $(1.48)$ \\
\hline \multirow[t]{2}{*}{ Yr2005 } & 0.58 & 0.57 \\
\hline & $(6.13)^{* * *}$ & $(3.75)^{* * *}$ \\
\hline \multirow[t]{2}{*}{ Yr2006 } & 0.63 & 0.60 \\
\hline & $(5.99)^{* * *}$ & $(3.38)^{* * *}$ \\
\hline \multirow[t]{2}{*}{ Yr2007 } & 0.45 & 0.82 \\
\hline & $(3.65)^{* * *}$ & $(4.60)^{* * *}$ \\
\hline \multirow[t]{2}{*}{ Yr2008 } & 0.93 & 1.14 \\
\hline & $(4.99)^{* * *}$ & $(5.26)^{* * *}$ \\
\hline \multirow[t]{2}{*}{ Intercept } & 21.13 & 38.92 \\
\hline & $(22.81)^{* * *}$ & $(2.46)^{* *}$ \\
\hline Adjusted $R^{2}$ & 0.27 & 0.25 \\
\hline
\end{tabular}

Observations are U.S. land designated for either condominium or multifamily development and span the sample period from 1999 to mid-2008.

$* * *, * *$, and * denote statistical significance at the 10 , 5 , and 1 percent levels, respectively.

\subsection{Differing times and places}

With the sample split based upon the range of prices within states, the results in Table 4 demonstrate the same structural break across the sample years as the full sample in Table 2 . Due to the enduring importance of the dichotomous time variables, we divide the sample into four subsamples using both low and high growth as well as early (1999-2003) and later (2004-2008) time periods. Table 5 reports the findings.

We observe a remarkable variance in the amount the two types of developers pay for land. The low-growth subsample during 19992003 exhibits a premium of 0.11 , which is similar to previous results. But, whereas the magnitude of the parameter estimates on Dev Type are similar in Columns 2 and 3 (i.e., 0.14 and 0.13 ), the coefficient estimates are not statistically significant. The p-values of these two slope coefficients are approximately 0.12 .

The distinct finding in Table 5 is the marginal slope on Dev Type in the high-growth markets for the period from 2004 to mid2008. The coefficient is 0.52 , which equates to a premium paid by condominium developers of $\$ 2,027,060$. Using Kennedy (1981), this amount is a 61 percent average premium paid by condominium over multifamily developers. And since this is an average amount, some condominium developers paid even more, all else equal. This stands in stark contrast to the insignificant marginal slopes for low-growth states during the same period as well as the same high-growth states during the earlier time period. Indeed, the Dev Type appears to be of such importance that the intercept in Column 4 is not significant.

Regarding other independent variables: (i) we note that income is a consistent determinant across markets as is residential demand; (ii) the magnitude of the marginal slope on SQFT is quite high in Column 4 (1.50) relative to the other specifications; and (iii) out-of-state buyers pay a significant premium for land in all four models, with the coefficient estimates increasing in size across specifications. The out-of-state parameter estimate of 0.71 in the high-growth states from 2004 to mid-2008 is a premium of approximately $\$ 3$ million or nearly double the price, on average. Lastly, we also observe that the year dummies are basically insignificant, which demonstrates that the models account for the time-series trends and splitting the samples across time is necessary. Likewise, the unique findings on Dev Type also implies the need to split the sample across above-average and below-average growth markets to determine the underlying nature of the price formation. 
Table 5. The table reports coefficients and heteroscedasity-consistent t-statistics (in parentheses) of subsamples split by the standard deviation of the natural logarithm of transaction prices (the dependent variable) as well as two time periods. YR1999 is the base year for 1999-2003 sample while YR2004 is the base for 2004-2008

\begin{tabular}{|c|c|c|c|c|}
\hline & $\begin{array}{l}\text { Low St.Dev. } \\
1999-2003 \\
\mathrm{~N}=1,669\end{array}$ & $\begin{array}{l}\text { Low St.Dev. } \\
2004-2008 \\
\mathrm{~N}=1,061\end{array}$ & $\begin{array}{l}\text { High St.Dev. } \\
1999-2003 \\
\mathrm{~N}=1,585\end{array}$ & $\begin{array}{l}\text { High St.Dev. } \\
2004-2008 \\
\mathrm{~N}=1,308\end{array}$ \\
\hline Dev Type & $\begin{array}{l}0.11 \\
(2.22)^{* * *}\end{array}$ & $\begin{array}{l}0.14 \\
(1.55)\end{array}$ & $\begin{array}{l}0.13 \\
(1.51)\end{array}$ & $\begin{array}{l}0.52 \\
(7.59)^{* * * *}\end{array}$ \\
\hline SQFT & 0.06 & 0.04 & 0.09 & 1.50 \\
\hline$\left(* 10^{-5}\right)$ & $(5.05)^{* * *}$ & $(0.77)$ & (1.18) & $(3.45)^{* * *}$ \\
\hline $\mathrm{SQFT}^{2}$ & -0.18 & -0.08 & -0.39 & -2.08 \\
\hline$\left({ }^{*} 10^{-13}\right)$ & $(-1.56)$ & $(-0.10)$ & $(-0.22)$ & $(-1.22)$ \\
\hline $\begin{array}{l}\text { Income } \\
\left(* 10^{-4}\right)\end{array}$ & $\begin{array}{l}0.27 \\
(4.60)^{* * * *}\end{array}$ & $\begin{array}{l}0.26 \\
(3.65)^{* * *}\end{array}$ & $\begin{array}{l}0.27 \\
(5.56)^{* * *}\end{array}$ & $\begin{array}{l}0.21 \\
(3.63)^{* * *}\end{array}$ \\
\hline $\begin{array}{l}\text { Res Demand } \\
\left({ }^{*} 10^{-4}\right)\end{array}$ & $\begin{array}{l}0.07 \\
(2.76)^{* * * *}\end{array}$ & $\begin{array}{l}0.11 \\
(4.03)^{* * * *}\end{array}$ & $\begin{array}{l}-0.06 \\
(-1.88)^{*}\end{array}$ & $\begin{array}{l}0.09 \\
(2.07)^{* * *}\end{array}$ \\
\hline OutState & $\begin{array}{l}0.41 \\
(5.96)^{* * * *}\end{array}$ & $\begin{array}{l}0.48 \\
(5.70)^{* * * *}\end{array}$ & $\begin{array}{l}0.56 \\
(5.15)^{* * * *}\end{array}$ & $\begin{array}{l}0.71 \\
(5.53)^{* * * *}\end{array}$ \\
\hline CBD & $\begin{array}{l}-0.01 \\
(-2.71)^{* * *}\end{array}$ & $\begin{array}{l}-0.01 \\
(-0.95)\end{array}$ & $\begin{array}{l}-0.04 \\
(-5.43)^{* * * *}\end{array}$ & $\begin{array}{l}-0.02 \\
(-2.47)^{* * *}\end{array}$ \\
\hline$\Delta$ Employment & $\begin{array}{l}0.00 \\
(0.14)\end{array}$ & $\begin{array}{l}-0.06 \\
(-0.67)\end{array}$ & $\begin{array}{l}-0.10 \\
(-2.44)^{* *}\end{array}$ & $\begin{array}{l}0.02 \\
(0.21)\end{array}$ \\
\hline Latitude & $\begin{array}{l}-0.27 \\
(-4.95)^{* * *}\end{array}$ & $\begin{array}{l}-0.35 \\
(-3.27)^{* * *}\end{array}$ & $\begin{array}{l}-1.99 \\
(-2.69)^{* * *}\end{array}$ & $\begin{array}{l}-1.05 \\
(-1.90)^{*}\end{array}$ \\
\hline Latitude $^{2}$ & $\begin{array}{l}0.00 \\
(4.16)^{* * *}\end{array}$ & $\begin{array}{l}0.00 \\
(2.04)^{* * *}\end{array}$ & $\begin{array}{l}0.03 \\
(2.61)^{* * * *}\end{array}$ & $\begin{array}{l}0.01 \\
(1.88)^{*}\end{array}$ \\
\hline Longitude & $\begin{array}{l}0.06 \\
(2.06)^{* * *}\end{array}$ & $\begin{array}{l}0.09 \\
(2.04)^{* *}\end{array}$ & $\begin{array}{l}0.11 \\
(1.36)\end{array}$ & $\begin{array}{l}0.06 \\
(0.92)\end{array}$ \\
\hline Longitude $^{2}$ & $\begin{array}{l}0.00 \\
(2.12)^{* *}\end{array}$ & $\begin{array}{l}0.00 \\
(2.06)^{* *}\end{array}$ & $\begin{array}{l}0.00 \\
(1.33)\end{array}$ & $\begin{array}{l}0.00 \\
(1.04)\end{array}$ \\
\hline Yr2000 & $\begin{array}{l}-0.09 \\
(-0.77)\end{array}$ & & $\begin{array}{l}-0.01 \\
(-0.05)\end{array}$ & \\
\hline Yr2001 & $\begin{array}{l}-0.20 \\
(-1.28)\end{array}$ & & $\begin{array}{l}-0.36 \\
(-1.71)^{*}\end{array}$ & \\
\hline Yr2002 & $\begin{array}{l}-0.43 \\
(-1.79)\end{array}$ & & $\begin{array}{l}-0.26 \\
(-0.85)\end{array}$ & \\
\hline Yr2003 & $\begin{array}{l}-0.48 \\
(-1.51)\end{array}$ & & $\begin{array}{l}-0.15 \\
(-0.39)\end{array}$ & \\
\hline Yr2005 & & $\begin{array}{l}-0.02 \\
(-0.12)\end{array}$ & & $\begin{array}{l}-0.05 \\
(0.37)\end{array}$ \\
\hline Yr2006 & & $\begin{array}{l}-0.21 \\
(-0.86)\end{array}$ & & $\begin{array}{l}-0.28 \\
(-1.24)\end{array}$ \\
\hline Yr2007 & & $\begin{array}{l}-0.72 \\
(1.83)^{*}\end{array}$ & & $\begin{array}{l}-0.34 \\
(-0.86)\end{array}$ \\
\hline Yr2008 & & $\begin{array}{l}-0.44 \\
(-0.84)\end{array}$ & & $\begin{array}{l}-0.13 \\
(-0.22)\end{array}$ \\
\hline Intercept & $\begin{array}{l}12.41 \\
(3.53)^{* * *}\end{array}$ & $\begin{array}{l}11.28 \\
(1.90)^{*}\end{array}$ & $\begin{array}{l}55.40 \\
(3.57)^{* * *}\end{array}$ & $\begin{array}{l}19.94 \\
(1.47)\end{array}$ \\
\hline Adjusted $\mathrm{R}^{2}$ & 0.22 & 0.24 & 0.16 & 0.23 \\
\hline
\end{tabular}

The sample consists of U.S. land designated for either condominium or multifamily projects from 1999 to mid-2008. $* * *, * *$, and * denote statistical significance at the 10, 5, and 1 percent levels, respectively. 


\section{CONCLUSION}

In the process of investigating the competition between multifamily and condominium developers for raw land throughout the U.S. from 1999 to mid-2008, we find (i) that there exist two distinct subperiods during the sample and (ii) a difference between lower- and higher-growth states. After accounting for these different subsamples, the results demonstrate that condominium developers pay a premium for land. However, the premium is not always statistically significant, thus, we can not infer a domination of the condominium product over the long run.

Despite the lack of a significant relation across all subsamples we observe a tremendous premium paid by condominium developers in the high-growth states during the heady period from 2004 to mid-2008. Indeed, some condominium developers paid a premium greater than 60 percent over the transaction prices for multifamily designated property.

In addition to determining a possible relation between prices for multifamily versus condominium-designated land, the findings provide an important valuation conclusion. The extraordinary premium calls into question the price formation process in the high-growth states. In this regard, the premium is a cautionary warning to valuers using transactions in these areas as sales comparables. Indeed, the exuberant period in the mid-2000s may cause valuation issues in all types of future appraisals.

\section{REFERENCES}

Benjamin, J., Chinloy, P., Hardin, W. and Wu, Z. (2008) Clientele effects and condo conversions, Real Estate Economics, 36(3), pp. 611-634. doi:10.1111/j.1540-6229.2008.00224.x

DiPasquale, D. and Wheaton, W. (1992) The markets for real estate assets and space: A conceptual framework, Journal of the American Real Estate and Urban Economics Association, 20(2), pp. 181-197. doi:10.1111/1540-6229.00579

Eppli, M.J., Shilling, J.D. and Vandell, K.D. (1998) What moves retail property returns at the metropolitan level? Journal of Real Estate Finance and Economics, 16(3), pp. 317-342. doi:10.1023/A:1007783900583

Fik, T., Ling, D. and Mulligan, G. (2003) Modeling spatial variation in housing prices: A variable interaction approach, Real Estate Economics, $31(4)$, pp. $623-646$. doi:10.1046/j.1080-8620.2003.00079.x

Fisher, J. (1992) Integrating research on markets for space and capital, Journal of the American Real Estate and Urban Economics Association, 20(2), pp. 161-180. doi:10.1111/1540-6229.00578

Geltner, D. and Miller, N. (2001) Commercial Real Estate Analysis and Investments. New Jersey: Prentice Hall.

Geltner, D. and Mei, J. (1995) The present value model with time-varying discount rates: Implications for commercial property valuation and investment decisions, Journal of Real Estate Finance and Economics, 11(2), pp. 119-136. doi:10.1007/BF01098657

Kennedy, P. (1981) Estimation with correctly interpreted dummy variables in semilogarithmic equations, American Economic Review, 71(4), p. 801.

Lambson, V., McQueen, G. and Slade, B. (2004) Do out-of-state buyers pay more for real estate? An examination of anchoring-induced bias and search costs, Real Estate Economics, 32(1), pp. 85-126. doi:10.1111/j.1080-8620.2004.00085.x

Miles, M., Berens, G., Eppli, M. and Weiss, M. (2007) Real Estate Development. Washington, D.C.: The Urban Land Institute.

Scheinkman, J. and Xiong, W. (2003) Overconfidence and speculative bubbles, Journal of Political Economy, 111(6), pp. 1183-1219. doi:10.1086/378531 


\section{SANTRAUKA}

\section{RINKOS KONKURENCIJA DE்L GYVENAMŲJŲ SKLYPŲ SU DIDELIU GYVENTOJŲ TANKUMU}

\section{Matthew L. CYPHER, Darren K. HAYUNGA}

Savo darbe nagrinejjame potencialią konkurencija tarp daugiabučiu namų ir kooperatiniu namų vystytojų dèl žemės sklypu visoje JAV teritorijoje. Nagrinėdami visa imties laikotarpi, aptinkame iૃrodymu, kad kooperatiniu namu vystytojai už sklypus vidutiniškai mokejjo daugiau nei jų kolegos, statantys daugiabučius namus. Kita vertus, suskirsčius imti i lètai ir sparčiai besivystančias vietoves bei du laikotarpius, pastebima, kad priemoka ne visiškai pastovi. Regis, priemokų vidurkị iš esmės lemia sparčiai besivystančios vietovès ir laikotarpis nuo 2004 m. iki 2008 m. vidurio. Iš tiesu rezultatai rodo, kad per ši laikotarpi kooperatinių namų vystytojai sparčiai besivystančiose valstijose už sklypus mokejjo per 60 proc. daugiau. Tokia neitikètina priemoka verčia abejoti tose vietovėse taikomu kainodaros procesu. 